\title{
Yenilenebilir Enerji Yatırımları ve İstihdam İlişkisi: E-7 Ülkeleri Üzerine Bir Analiz
}

\author{
Muharrem AFŞAR (https://orcid.org/0000-0002-4071-9330), Anadolu University, Turkey; \\ mafsar@anadolu.edu.tr
}

Başak ÖZARSLAN-DOĞAN (https://orcid.org/0000-0002-5126-7077), Anadolu University, Turkey; bozarslan@anadolu.edu.tr

\section{Relation of Renewable Energy Investments and Employment: An Analysis on E-7 Countries}

\begin{abstract}
In general, one of the most important economic problems in all economies, especially in the E-7 countries, is low employment. In this sense, it is of great importance to adopt policies to increase employment in these countries. In this context, the relationship between employment and investment in renewable energy is analysed with the help of "Panel ARDL Method PMG Estimator" using the data set for the period 2000-2019 for E-7 countries. The study includes fixed asset investment, economic growth, inflation, and total labour force in addition to renewable energy investment in the analysis. The result of the analysis: it was found that renewable energy investment, economic growth, and fixed investment have a positive effect on employment, while total labour force and inflation have a negative effect.

Keywords : Renewable Energy, Employment, Panel Data Analysis.

JEL Classification Codes : $\quad$ C33, E24, O13.

\section{$\ddot{\mathbf{O} z}$}

Genel olarak bütün ekonomilerde, özellikle E-7 ülkelerinde temel ekonomik sorunlardan birisini düşük istihdam seviyeleri oluşturmaktadır. Bu anlamda söz konusu ülkelerde istihdam seviyesini arttıracak politikaların uygulanması büyük önem taşımaktadır. Bu kapsamda çalışmada istihdam ve yenilenebilir enerji yatırımları arasındaki ilişki E-7 ülkeleri için 2000-2019 dönemi veri seti yardımıyla "Panel ARDL Yöntemi PMG Tahmincisi" kullanılarak analiz edilmektedir. Çalışmada yenilenebilir enerji yatırımlarının yanı sıra, sabit sermaye yatırımları, ekonomik büyüme, enflasyon ve toplam işgücü de analize dahil edilmiştir. Analiz sonucunda; yenilenebilir enerji yatırımları, ekonomik büyüme ve sabit sermaye yatırımlarının istihdam üzerinde pozitif, toplam işgücü ve enflasyonun ise negatif bir etkiye sahip olduğu tespit edilmiştir.
\end{abstract}

Anahtar Sözcükler $\quad$ : Yenilenebilir Enerji, İstihdam, Panel Veri Analizi. 


\section{Giriş}

İçinde bulunduğumuz sosyoekonomik süreç, dünyada her geçen gün daha yoğun enerji kullanımına ve artan bir enerji talebine neden olmaktadır. Enerji talebin karşılanmasında ise kömür, petrol ve doğalgaz gibi fosil kökenli enerji kaynakları yoğun şekilde kullanılmaktadır. Karbon salınımı yüksek bu kaynakların kullanımının, artan küresel 1sınma ve iklim değişikliği gibi çevresel sorunlara neden olması, dikkatleri yenilenebilir enerji kaynaklarına yöneltmektedir. Yenilenebilir enerji kaynaklarının tekrar tekrar kullanıma müsait olması ve çevre dostu olmaları nedeniyle, küresel iklim değişikliği ile mücadelede oldukça önemli bir etkiye sahip olduğu bilinmektedir. Bu bağlamda, yenilebilir enerji kaynakları kullanılarak üretilen yenilenebilir enerjinin önemi, her geçen gün artmakta ve dikkatleri üzerine çekmektedir.

Enerji kaynakları temel olarak fosil, yenilenebilir ve nükleer enerji kaynakları olarak sınıflandırılmaktadır. Yenilenebilir enerji kaynakları ise hidroelektrik, rüzgâr, güneş, biokütle, okyanus enerjisi, jeotermal vb. kaynaklar olarak alt sinıflandırmaya tabi tutulmaktadır. Artan enerji ihtiyacının karşılanmasında kullanılan fosil yakıtların, rezerv sorununun olması, coğrafi ve siyasi çatışmalar yaratması ve arz güvenliği endişesi gibi nedenler göz önüne alındığında, yenilenebilir enerji kaynakları fosil yakıtlara iyi bir alternatif oluşturmaktadır. Bu bağlamda yenilenebilir enerji kaynakları, günümüzde şimdilik toplam dünya enerjisinin yaklaşık \%15-20'sini sağlamaktadır (Kumar, 2019).

Sekil: 1

Küresel Yenilenebilir Enerji Kapasitesi, 2004-2018, GW

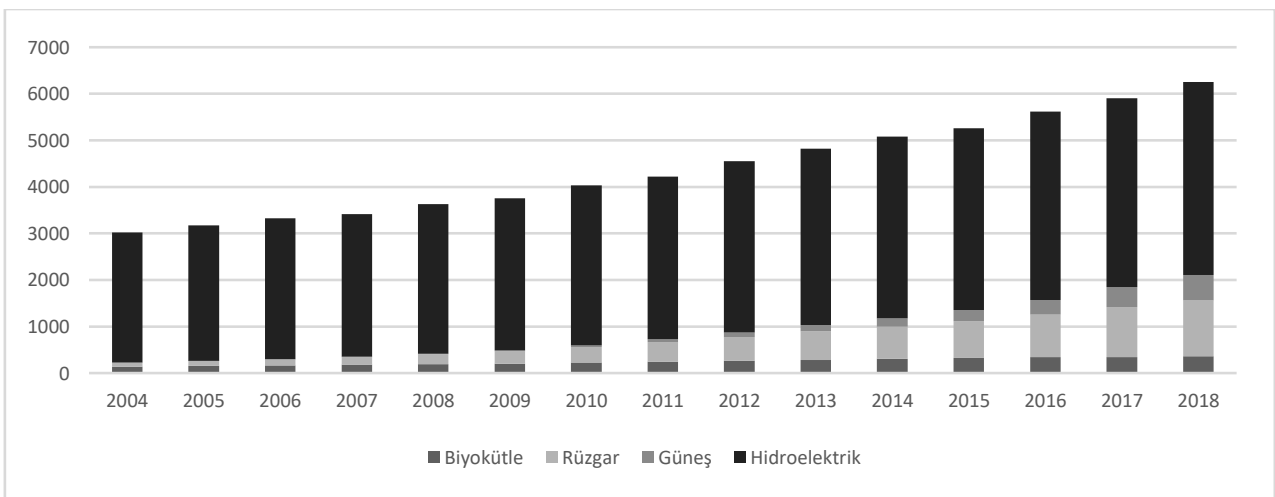

Kaynak: IRENA, 2020.

Şekil 1'den görüldüğü gibi, başta güneş ve rüzgâr olmak üzere yenilenebilir enerji kapasitesi sürekli bir artı̧̧ eğilimi içindedir. Yenilenebilir enerji kapasitesinin artış göstermesi ise iklim değişikliği, toplumsal farkındalık, fosil yakıtların fiyatlarında zaman 
zaman ortaya çıkan belirsizlikler gibi nedenlere dayanmaktadır. Bununla birlikte, bu artıştaki en önemli etken, kuşkusuz yenilenebilir enerji yatırımlarında ortaya çıkan maliyet düşüşleri olmaktadır. Uluslararası Yenilenebilir Enerji Ajansı'nın (IRENA) yayınladığı "'Yenilenebilir Enerji Üretim Maliyetleri'” adlı rapora göre; 2010-2019 döneminde güneş enerjisini elektrik akımına dönüştüren teknoloji olarak bilinen fotovoltaik güneş enerjisinde $\% 82$, yoğunlaştırılmış güneş enerjisinde $\% 47$, kara rüzgarında $\% 39$ ve deniz üstü rüzgâr enerjisinde ise \%29 maliyet azalışı olduğu bildirilmiştir (IRENA, 2019).

Günümüzde karbon emisyonunun büyük bir kısmı, fosil yakıtların yanmasından kaynaklanmaktadır. Bu bağlamda, fosil yakıtların kullanımının kısılması, karbon emisyonlarının azaltılmasında büyük önem taşımaktadır (Kralova \& Sjöblom, 2010: 409). Yenilenebilir enerji kaynaklarının kullanımına ilişkin 2040 yılına kadar tahmin edilen küresel senaryo Tablo 1'de görülmektedir.

Tablo: 1

2040 Yılına kadar Tahmin Edilen Küresel Yenilenebilir Enerji Senaryosu

\begin{tabular}{|c|c|c|c|c|c|}
\hline & 2001 & 2010 & 2020 & 2030 & 2040 \\
\hline Toplam Tüketim (MTEP) & 10,038 & 10,549 & 11,425 & 12,352 & 13,31 \\
\hline Biokütle & 1080 & 1313 & 1791 & 2483 & 3271 \\
\hline Hidroelektrik (Küçük Ölçekli) & 9,5 & 19 & 49 & 106 & 189 \\
\hline Hidroelektrik (Büyük Ölçekli) & 22 & 266 & 309 & 341 & 358 \\
\hline Jeotermal & 43 & 86 & 186 & 333 & 493 \\
\hline Rüzgâr & 4,7 & 44 & 266 & 542 & 688 \\
\hline Güneş & 4,3 & 17,4 & 93 & 481 & 872 \\
\hline Elektrik Üretimine Katkısı (\%) & 13,6 & 16,6 & 23,6 & 34,7 & 47,7 \\
\hline
\end{tabular}

Kaynak: Kralova \& Sjöblom, 2010: 410.

Buna göre; 2040 yılına gelindiğinde küresel enerji arzının yaklaşık yarısı yenilenebilir enerji kaynaklardan karşılanacaktır. Bu kaynaklar içerisinde ise biokütle, güneş ve rüzgâr enerjisinin ise daha bir ön plana çıkacağı görülmektedir. Ayrıca, güneş ve rüzgâr enerjisinin yanında, biokütle enerjisinin, gelişmiş ülkelerin sahip olduğu modern teknolojiler nedeniyle de daha yoğun kullanım oranlarına kavuşacağı tahmin edilmektedir.

Nüfus ve büyümenin sürekli artması, aynı zamanda daha fazla üretim ve buna bağlı olarak da daha fazla enerji ihtiyacı anlamına gelmektedir. Bu artan enerji ihtiyacının ise fosil kaynaklar yerine yerinebilir kaynaklardan karşılanması daha sürdürülebilir bir çevre ve daha sürdürülebilir bir ekonomik büyümenin sağlanması açısından da önemlidir (Öymen \& Ömeroğlu, 2020: 1072). Diğer taraftan yenilenebilir enerji sektörel olarak değerlendirildiğinde, birçok ülkede halen daha yeni olan bir sektördür. Bu nedenden dolayı sektör, hem birçok yatırımcıyı çekebilecek kadar cazip hem de yeni olmasından dolayı içerdiği belirsizlikler nedeniyle yatırımcılar için riskli olabilmektedir. Fakat bu noktada çeşitli hükümet ve devlet teşviklerinin uygulanması, riski en aza indirmede büyük önem taşımakta ve bu alana yapılacak yatırımlarında önünü açmaktadır. Bu bağlamda yenilenebilir enerji sektöründe yatırım miktarının artması, başta gelişmekte olan ülkeler olmak üzere birçok ülkede işsizlik oranlarının düşürülmesine katkı sağlayabilir. Böylece ülke 
ekonomileri arasındaki farklılıkların giderilmesine yardımcı olacağı düşünülmektedir. Yenilenebilir enerjide yüksek yatırım miktarları ve kurulu güç kapasitesindeki artış hem bu sektörde hem de ülke genelindeki istihdam üzerinde de önemli katkılar sağlayacaktır (Lehr vd., 2008: 109).

\section{Yenilenebilir Enerji ve İstihdam}

Enerji sektöründe, yaşanan enerji arz güvenliği problemi ve küresel iklim değişikliğinin zorunlu hale getirdiği bir dönüşümün yaşandığ gözlenmektedir. Bu dönüşüm; yaşanan teknolojik gelişmeler ve hükümetlerin uyguladığı çeşitli teşvik politikalarıyla, özellikle 90'lı yıllardan sonra dinamik bir hale gelmiştir. $\mathrm{Bu}$ ve benzeri gelişmeler doğrultusunda, dünya ülkeleri yenilenebilir enerji kaynaklarına yönelmiş ve ilerleyen yıllar için kendilerine çeşitli hedefler belirlemişlerdir. Bu bağlamda, örneğin, Danimarka ve İskoçya'nın \%100, Almanya ve Litvanya'nın ise \%60 yenilenebilir enerji hedefi koyması, sektördeki beklentilerin artmasına neden olmaktadır (REN21, 2016: 26-35, Ağpak \& Özçiçek, 2018: 113). Yenilenebilir enerji sektöründeki beklentilerin artması, sektörün özellikle büyüme ve istihdam başta olmak üzere, makroekonomik etkilerinin araştırılmasını gerekli kılmaktadır.

Son yıllarda yenilenebilir enerji alanındaki gelişmeler dikkate alındığında, daha çok gelişmiş ülkelerde mevcut olan toplam kurulu güç kapasitenin, özellikle 2000'li yıllardan sonra, Çin ve Hindistan gibi gelişmekte olan ülkelere de kaymaya başladığ Fakat gelişmekte olan ülkelerin en büyük sorunlarından biri, artan nüfusa paralel şekilde ortaya çıkan işgücündeki artışlardır. Bu sebepten dolayı, gelişmekte olan ülkeler, işgücü artışına paralel bir istihdam kapasitesi geliştiremediği için, düşük istihdam, yüksek işsizlik oranlarına sahiptir (Aksu, 2017: 41). Yenilenebilir enerji yatırımlarının artışı, iktisat teorisinde yatırımların istihdam artırıcı etkisi bağlamında düşünüldüğünde, uygulandığı ülkede istihdam artışı ve işsizlik oranlarında azalış yaratması, teoriden gelen bir beklenti oluşmasına neden olmaktadır.

İşsizlik oranının uzun süre doğal oranın üzerinde seyretmesi hem insan sermayesinde azalmaya hem de toplumsal sorunların artmasına yol açmaktadır. Özellikle son yıllarda istihdam oranlarını artırıcı politikaların uygulanması, tıpkı küresel 1sınma ve iklim değişikliği gibi, önemli konular arasında yer almaktadır. İlgili süreçte, yenilenebilir enerji sektörünün desteklenmesi, çoğu ülkede istihdam politikası aracı olarak da işlev görmektedir. (Markandya vd., 2016: 1342; Cameron \& van der Zwaan, 2015: 161; European Comission, 2014; Ağpak \& Özçiçek, 2018: 113).

Yapılan çalışmalar da ilgili sektördeki istihdam gelişimi hakkında ön bilgiler sunmaktadır. Bu bağlamda, 2013 yılında 6,5 milyon kişi yenilenebilir enerji ile ilgili işlerde çalışırken, 2019 yılında doğrudan veya dolaylı olarak yaklaşık 11,5 milyon kişi söz konusu sektörde istihdam edildiği, bu istihdamın büyük bölümünün ise güneş, hidroelektrik, rüzgâr 
ve biokütle enerjisi sektöründe gerçekleştirildiği ifade edilmektedir (IRENA, 2020). Buna göre, ilgili süreçte dünya genelinde yeni 5,5 milyon kişilik istihdamın oluşması, yenilenebilir enerjinin istihdam oluşturma kapasitesi açısından dikkat çekicidir. Tablo 2'de 2012-2019 yılları arasında, teknoloji bazında küresel yenilenebilir enerji istihdamı gösterilmektedir. Buna göre; ilgili dönemde en çok istihdamın yaratıldığı yenilenebilir enerji teknolojisi, güneş enerjisi ve biokütle olmuştur. Hidroelektrikte ise istihdam artırıcı kapasite, ifade edilen yıllarda güneş ve biokütlenin arkasından üçüncü sırada yer almaktadır.

Tablo: 2

Teknoloji Bazında Küresel Yenilenebilir Enerji İstihdamı (Milyon Kişi 2012-2019)

\begin{tabular}{|c|c|c|c|c|c|c|}
\hline Yillar & Hidroelektrik & Güneș & Rüzgâr & Biokütle & Diğer & Toplam \\
\hline 2012 & 1.66 & 2.25 & 0.75 & 2.40 & 0.22 & 7.28 \\
\hline 2013 & 2.21 & 2.77 & 0.83 & 2.50 & 0.23 & 8.55 \\
\hline 2014 & 2.04 & 3.25 & 1.03 & 2.99 & 0.19 & 9.50 \\
\hline 2015 & 2.16 & 3.71 & 1.08 & 2.88 & 0.20 & 10.04 \\
\hline 2016 & 2.06 & 3.92 & 1.16 & 2.74 & 0.24 & 10.13 \\
\hline 2017 & 1.99 & 4.18 & 1.15 & 3.05 & 0.16 & 10.53 \\
\hline 2018 & 2.05 & 4.48 & 1.16 & 3.18 & 0.18 & 10.98 \\
\hline 2019 & 1.95 & 4.57 & 1.17 & 3.58 & 0.18 & 11.46 \\
\hline
\end{tabular}

Kaynak: IRENA (2020), Renewable Energy and Jobs- Annual Review 2020.

Yenilenebilir enerji ve yatırımları nasıl olur da istihdama etki eder sorusu, çalışmanın amacı bağlamında düşünüldüğünde oldukça önemlidir. Yatırımların zaten bilinen istihdam etkisi dışında, aslında yenilenebilir enerji kaynaklarından etkin bir şekilde yararlanabilmek için, sektöre özgü önemli gerekliliklerin olduğu ifade edilmektedir. Bu gerekliliklerin başında, tasarlanan yenilenebilir enerji projelerinde üretiminin verimliliğini sağlayacak, uygun çalışma ekibi kurulması gelir. Ayrıca yenilenebilir enerji projelerine yatırım konusunda, danışmanlık hizmeti verecek nitelikli insanlara ihtiyaç olmaktadır. İlgili projelerin ülke içinde uygulanmasının sağlanması için, yeterli niteliklere sahip hukuk uzmanlarının varlığı da ayrı bir gereklilik olarak karşımıza çıkmaktadır (Yüksel vd. 2020). Öte yandan, teknik çalışmaların gerçekleştirilmesinde mühendis ve teknikerlere ihtiyaç duyulmaktadır. Bu bağlamda özellikle son yıllarda mühendislik ve teknikerlik işlerinin çoğunun, yenilenebilir enerji alanına yönlendirildiği de bir gerçektir (Lund, 2009; Dinçer \& Karakuş, 2020). Bu benzeri durumların mevcudiyeti göstermektedir ki, yenilenebilir enerji yatırımlarının, özellikle belli alanlardaki istihdam üzerinde etkilerinin olması beklenir.

Yenilenebilir enerji alanında, gelişmiş ve gelişmekte olan pek çok ülkede gerek satış ve kurulum gerek işletme ve bakım gibi aşamalarda, istihdam olanakları giderek artmaktadır. Özellikle Çin, Hindistan, Brezilya, ABD ve AB ülkeleri söz konusu alanda yüksek istihdam olanağı yaratma konusunda, öne çıkan ülkelerdir (Kaya, 2020: 17). Aşağıdaki Tablo 3’te Çin, Hindistan, Brezilya, $A B D$ ve $A B$ ülkelerine ait yenilenebilir enerji istihdam verileri görülmektedir. Buna göre; her ülkenin farklı özelliklerine göre öne çıkan yenilenebilir enerji sektörleri olmasına karşın, genel olarak en fazla istihdamın güneş ve biokütle enerjisinde yaratıldığı görülmektedir. Özellikle Çin hem güneş enerjisinde hem de rüzgâr enerjisinde bir 
liderlik sağlarken, Brezilya biokütle alanında en çok istihdama sahiptir. Mevcut durumda Brezilya'nın, küresel biyoetanol ihracının yaklaşık \%50’ye yakınını gerçekleştirmesi, ülkenin ilerleyen dönemlerde bu alanda yeni tesisler kurma planlarının bulunması, istihdam olanaklarını daha da arttıracağına işaret etmektir.

Türkiye'de yenilenebilir enerji kaynaklarının gelişimi 2000'li yıllardan sonra artmaya başlamıştır. 2005 yılında yürürlüğe giren "Yenilenebilir Enerji Kaynaklarının Elektrik Enerjisi Üretimi Amaçlı Kullanımına İlişkin Kanun” ile birlikte, özellikle rüzgâr ve güneş gibi yenilenebilir enerji kaynaklarının yatırımlarında artışlar yaşanmıştır. Ayrıca, yenilenebilir enerji yatırımlarında yerli üretime sağlanan teşvikler de yenilenebilir enerji yatırımlarındaki artışta önemli bir etkendir. Şekil 2, Türkiye'de 2020 yılına ait yenilenebilir enerji istihdamına yönelik son verilerinin izlenebilmesi açısından önemlidir.

Tablo: 3

Yenilenebilir Enerji İstihdamında Öne Çıkan Ülkeler ve İstihdam Miktarları, 2019 (Bin Kişi)

\begin{tabular}{|l|c|c|c|c|c|}
\hline & Çin & Brezilya & Hindistan & ABD & AB \\
\hline Güneș & 2884 & 87 & 227 & 245 & 163 \\
\hline Rüzâr & 518 & 19 & 63 & 120 & 292 \\
\hline Biyokütle & 384 & 839 & 178 & 355 & 706 \\
\hline Hidroelektrik & 561 & 213 & 367 & 22 & 78 \\
\hline Jeotermal & 3 & - & - & 9 & 40 \\
\hline
\end{tabular}

Kaynak: IRENA (2020), Renewable Energy and Jobs-Annual Review 2020.

Şekil: 2

Türkiye'de Yenilenebilir Enerji İstihdamı, 2020 (Bin Kişi)

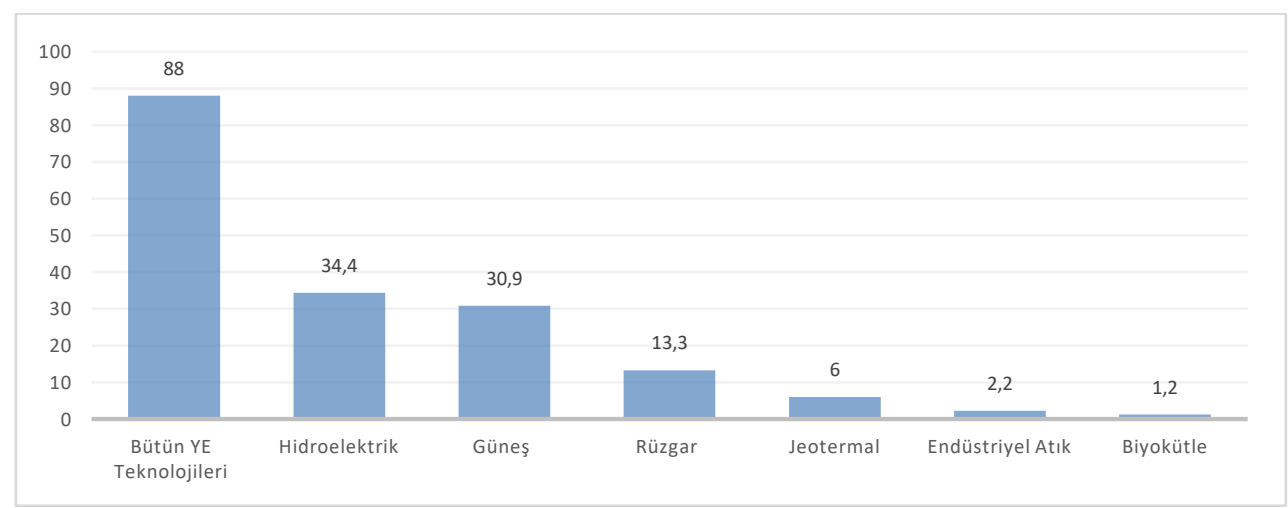

Kaynak: IRENA (2020), Renewable Energy and Jobs-Annual Review 2020.

Tabloya göre; Türkiye'de en yüksek istihdama sahip yenilenebilir enerji kolu hidroelektrik sektörü olarak görülmektedir. Sektörde yaklaşık 35 bin kişilik bir istihdam yaratılmıştır. Hidroelektriği sırasıyla, yaklaşık 30 bin kişi ile güneş, yaklaşık 13 bin kişi ile 
rüzgâr ve yaklaşık 6 bin kişi ile de jeotermal enerji takip etmektedir. Biokütle ve endüstriyel atık sektöründeki istihdam oranları ise nispeten daha az olarak görünmektedir. Bunun yanında 2020 yılında Türkiye'de yenilenebilir enerji sektöründe yaratılan toplam istihdamın ise 88 bin olduğu görülmektedir.

\section{Literatür Taraması}

Son yıllarda ekonomi literatüründe yenilenebilir enerji ile ilgili birçok çalışma yapılmıştır. Ancak yapılan çalışmaların büyük bir bölümünün, yenilenebilir enerjinin belirleyicilerine yönelik olduğunu söyleyebiliriz. Bunun dışında özellikle yenilenebilir enerjinin gelir üzerindeki etkileri de araştırılan konular arasındadır. Yenilenebilir enerji kaynakları ile ilgili araştırmalar yaygınlaştıkça, ilgili alanın farklı makroekonomik etkilerinin araştırılması da beklenmelidir.

Yenilenebilir enerji yatırımlarının istihdam üzerindeki etkilerinin tespitine yönelik, literatürde nispeten sınırlı çalışma örneği bulmaktadır. Yapılan çalışmaların büyük çoğunluğu ise, analitik değil, daha çok teorik saptamaları içermektedir. Konu ile ilgili yaptığımız bu çalışmanın, yazında tespit edilen eksikliğin giderilmesine katkı sunacağı düşünülmektedir. Çalışmanın bu bölümünde, ilgili konudaki literatür taramasına özet olarak yer verilmektedir:

Ağpak ve Özçiçek (2018) yaptıkları çalışmada, yenilenebilir enerji kullanımının istihdam üzerindeki etkisinin belirlenmesinde Ortak İlişkili Etkiler Ortalama Grup (CCEMG) Tahmincisini kullanarak 59 ülke için 1991-2014 dönemini kapsayan bir analiz gerçekleştirmişlerdir. Elde edilen analiz sonuçlarına göre, yenilenebilir enerji kullanımı ile istihdam oranları arasında negatif bir ilişki bulunmuştur.

Apergis ve Salim (2015), 80 ülke için 1990-2013 dönemini kapsayan çalışmalarında, yenilenebilir enerji tüketiminin işsizlik oranları üzerindeki etkisini Panel veri ve Granger Nedensellik analizi yardımı ile incelemişlerdir. Elde edilen sonuçlarda, genel olarak yenilenebilir enerjinin işsizlik üzerindeki etkisinin pozitif yönde olduğu, bunun nedeni olarak da yenilenebilir enerjinin istihdam yaratma potansiyelinin maliyete bağlı olduğunu ifade etmişlerdir.

Apergis ve Payne (2010) çalışmalarında yenilenebilir enerji kullanımı ve ekonomik büyüme ilişkisini, 1992-2007 dönemi veri seti ve Avrasya kıtasında yer alan 13 ülke için Panel eşbütünleşme, nedensellik ilişkisi yardımıyla incelemişlerdir. Çalışmada kontrol değişken olarak istihdam oranları kullanılmıştır. Buna göre elde edilen sonuçlar, yenilenebilir enerji ve istihdam arasında tarafsızlık hipotezinin geçerli olduğunu kanıtlar niteliktedir. 
Aşkın ve Aşkın (2019) yenilenebilir enerji sektörünün istihdam yaratma potansiyelini teorik olarak incelemişlerdir. Buna göre, yenilenebilir enerji sektörüne yapılan yatırımların, yurt içindeki sektörlerin yerlileştirilmesi ve millileştirilmesi ile birlikte gerçekleştiği takdirde, istihdam artışının daha fazla olacağını ortaya koymuşlardır.

Özsoy ve Özpolat (2020) yüksek gelirli gelişmekte olan BRICS ve MIST ülkelerinde 1991-2014 dönemi için, yenilenebilir enerji, yenilenemeyen enerji ve istihdam arasındaki nedensellik ilişkisini Bootstrapt Granger Nedensellik Analizi aracılığg ile incelemişlerdir. Elde edilen analiz sonucuna göre; Rusya, Hindistan ve Endonezya'da yenilenebilir enerji ve istihdam arasında çift yönlü nedensellik ilişkisi bulunurken, Güney Afrika ve Türkiye'de yenilenebilir enerjiden istihdama doğru bir nedensellik tespit edilmiştir. Çin, Güney Kore ve Meksika'da ise yenilenebilir enerji ve istihdam arasında nedensellik ilişkisi tespit edilememiştir.

Elfani (2011) Endonezya için, yenilenebilir enerjinin istihdam üzerindeki etkisini teorik boyutları ile incelemiştir. Buna göre 2011 döneminde Endonezya'nın işsizlik oranlarının düşürülmesinde yenilenebilir enerji alanında kapasite artışının etkili olabileceği sonucuna ulaşmıştır. Gelecek yıllarda Endonezya'da yenilenebilir enerji yatırımlarının artışı ile istihdam oranlarının da artması tahmin edilmektedir.

Karaca ve Eşgünoğlu (2017) Türkiye'nin elektrik üretiminde yenilenebilir enerjinin payının \%100 olması durumunda, söz konusu sektöre ek yatırımların istihdam üzerindeki etkisini tahmin etmek için bir çalıştırma gerçekleştirmişlerdir. Ek yatırımlarda hangi yenilenebilir kaynağa ne kadar pay ayrılacağ 1 COPRAS çok kriterli karar verme yöntemiyle belirlenirken, yenilenebilir enerji yatırım büyüklüklerinin ülkedeki istihdama yapacağı katkı ise JEDI modeline göre tahmin edilmiştir. Buna göre, fosil yakıtlı santraller yerine kurulacak 56 Bin MW büyüklüğündeki yenilenebilir enerji santrallerinin kurulumu, ülkede yaklaşık 1.132.500 kişiye istihdam sağlayacağı tahmin edilmiştir.

Kaya (2020) yenilenebilir enerji istihdamında küresel durum değerlendirmesi gerçekleştirmiştir. Buna göre işgücü piyasalarını etkileyen politikaların etkin işlemesi durumunda yenilenebilir enerji istihdamının artacağını düşünmektedir. Bu noktada Çin özellikle güneş enerjisinde, ABD ve Brezilya biyoyakıt enerjisinde istihdam artışına öncülük ederken, Hindistan'da yenilenebilir enerji yatırımlarının artması kırsal kesimde işsizliğin azalmasına katkı sağlayacağını öngörmektedir.

Lehr vd. (2008) Almanya için yaptıkları çalışmada yenilenebilir enerji sektörü ve istihdam arasındaki ilişkiyi 1000 kişilik kapsamlı bir anket oluşturarak incelemişlerdir. Elde edilen bulgulara göre Almanya'nın yenilenebilir enerji alanındaki konumunu muhafaza etmesi durumunda 2030 yılına kadar yaklaşık 400.000'in üzerinde istihdam yaratma potansiyeli bulunmaktadir. 
Zhao ve Luo (2017) Çin için yaptıkları çalışmada 1978-2013 dönemi veri seti ile ARDL Sınır Testi aracılığıyla istihdamın yenilenebilir enerji üzerindeki etkilerini incelemişlerdir. Elde edilen bulgulara göre, Çin için belirtilen dönem aralığında istihdam, yenilenebilir enerji üzerinde uzun dönemde pozitif ve anlamlı bir ilişki içindedir.

Yukarıda literatür özetinden de anlaşıldığı gibi; yenilenebilir enerjinin istihdam etkisine yönelik yapılan çalışmalarda farklı sonuçlar mevcut olup, fikir birliği oluşturacak sonuçlar mevcut değildir. Sonuçlar, ele alınan ülkeye/bölgeye, yenilenebilir enerji teknolojisinin çeşidine, çalışmanın zaman aralığına ve çalışmada kullanılan modele göre değişebilmektedir.

$\mathrm{Bu}$ çalışmanın mevcut literatüre katkı sağlaması amacıyla, daha yeni verileri kullanarak ve örneklem alanını farklılaştırarak yeni bir denemeyi içermektedir. Bu bağlamda çalışma; 2000-2019 veri seti ve E-7 ülkeleri için, yenilenebilir enerjinin istihdam üzerindeki etkilerinin araştırılması kapsamında bir özgünlüğe sahiptir.

\section{Veri Seti ve Model}

Çalışma, 2000-2019 dönemine ait yıllık verilerle E-7 ülkelerinde yenilenebilir enerji yatırımlarının istihdam üzerindeki etkisini incelemeyi amaçlamaktadır. Brezilya, Çin, Hindistan, Endonezya, Meksika, Rusya ve Türkiye çalışmanın örneklemini oluşturmaktadır. Çalışmada E-7 ülkelerinin seçilme nedeni; son yıllarda hızlı ekonomik büyüme içinde olmaları ve gelecekte dünyanın ana üretim merkezi konumuna gelecekleri yönündeki beklentilerin yarattığı önemdir. Bunun yanı sıra başta Çin, Hindistan ve Brezilya olmak üzere E-7 ülkeleri, her yıl yenilenebilir enerji alanında yarattıkları kapasite artışı ve bu alandaki istihdam oranları anlamında da önemli ülkelerdir. Örneğin 2019 yılı itibariyle tüm yenilenebilir enerji işlerin yaklaşık \%40'ını Çin gerçekleştirirken, yaklaşık 830 bin istihdam ile Brezilya ise dünyanın en büyük sıvı biyoyakıt istihdamını gerçekleştirmektedir. Hindistan ise daha çok hidroelektrik, güneş ve rüzgâr enerjisi sektörlerine ağırlık vererek yaklaşık 720 bin kişilik istihdama sahiptir. Bununla birlikte güneş enerjisine yönelik istihdamda ilk 10 ülke arasında Çin, Hindistan ve Türkiye yer alırken, biokütle ve rüzgâr enerjisine yönelik istihdamda ilk 10 ülke arasında Çin, Hindistan ve Brezilya bulunmaktadır. Rusya ve Endonezya ise daha çok hidroelektrik enerjisi sektöründe istihdam gerçekleştirmektedir. Son olarak Meksika'da ise Brezilya'ya benzer şekilde en çok istihdam yaratılan sektör, biokütle enerjisi sektörüdür (IRENA, 2020).

Yenilenebilir enerji yatırımlarının istihdam üzerindeki etkisini araştırmak amacıyla kullanılan değişkenler, Tablo 4'te yer almaktadır. 
Tablo: 4

Ekonometrik Analizde Kullanılan Değişkenler ve Elde Edilen Kaynaklar

\begin{tabular}{|l|l|l|}
\hline Değişken & Tanımı & Kaynağ1 \\
\hline Băğılı Değişken & & \\
\hline EMP & Genel İstihdam Oranı-\% (15+ yaş) & Dünya Bankası-WDI \\
\hline Bă̆ımsız Değişkenler & & Dünya Bankası-WDI \\
\hline LBR & Toplam İşgücü & Dünya Bankası-WDI \\
\hline GRW & Ekonomik Büyüme-\% (Yıllık) & Dünya Bankas1-WDI \\
\hline GF & Sabit Sermaye Yatırımlarını GSYİH İçindeki Payı (\%) & Uluslararası Yenilenebilir Enerji Ajansı-IRENA \\
\hline LRE & Yenilenebilir Enerji Yatırımları (YE Elektrik üretim kapasitesi MW) & Dünya Bankası-WDI \\
\hline INF & Enflasyon-\% (Yıllık TÜFE) & \\
\hline
\end{tabular}

Yenilenebilir enerji yatırımlarının istihdam üzerinde yarattığı etkiyi ampirik olarak sınamak için tahmin edilen model Eşitlik 1 'de gösterilmiştir.

$$
\mathrm{EMP}=\beta_{0 \mathrm{i}}+\beta_{1 \mathrm{i} L L B R}+\beta_{2 \mathrm{i}} \mathrm{GRW}+\beta_{3 \mathrm{i}} \mathrm{GF}+\beta_{4 \mathrm{i}} \mathrm{LRE}+\beta_{5 \mathrm{i}} \mathrm{INF}+\varepsilon_{\mathrm{it}}
$$

İfade edilen model aracılığıyla uzun dönem denklemi ve parametre katsayılarına ulaşmak için izlenecek aşamalar aşağıda ifade edilmiştir:

- Yatay kesit bağımlılığg

- Serilerin durağanlığının belirlenmesi için birim kök testleri

- Kao (1999) Eşbütünleşme Testi

- Pesaran vd. (2007) tarafindan önerilen PMG Tahmincisi

Ekonometrik çalışmalarda, zaman serisi verileri, kesit verileri ve zaman serisi verileri ile kesit verilerinin bir birleşimi olan karma veriler olmak üzere üç tür veri kullanılmaktadır. Şayet, aynı kesit birimi belirli bir zaman içinde inceleniyorsa bu tür karma verilere panel veri adı verilmektedir (Gujarati, 1999).

Panel verinin kullanıldığı araştırmalarda genel olarak üç amaç bulunmaktadır. Bunlardan ilki, birimler arası değişkenliği veya her bir birimin zaman boyunca değişkenliğini tanımlamaktır. İkincisi, bu değişkenlikleri diğer bazı değişkenler bakımından açıklamaktır. Bu değişkenler cinsiyet gibi zaman boyunca sabit olacağı gibi, ruhsal durum gibi zaman içerisinde değişebilen türden olabilmektedir. Üçüncüsü ise her bir birimin ilgili değişken bakımından kestirimini yapmaktır (Hsiao, 2003: 89; Çemrek \& Burhan, 2014: 49). Panel veriler genel olarak Eşitlik 1'de ifade edildiği gibidir:

$$
Y_{\text {it }}=\beta_{0}+\beta_{1 i t} X_{1 i t}+\ldots+\beta_{\text {kit }} X_{\text {kit }}+e_{\text {it. }} i=1,2, \ldots . \mathrm{N} \mathrm{t}=1,2, \ldots \mathrm{T}
$$

Eşitlik 2'de yer alan i kesitleri, t ise zamanı ifade etmektedir. Y değişkeni ise her bir birimin her bir zaman periyodunda farklı değerlere sahip olduğu için i ve t olmak üzere iki alt göstergeyle ifade edilmiştir. 
Ekonometrik analizlerde serilerin durağanlıktan uzak olması durumunda, sahte regresyon denilen yanıltıcı sonuçlar ortaya çıkabilmektedir. Bu sebepten dolayı, serilerin durağanlığının test edilmesi ekonomerik analizler için büyük önem taşımaktadır (Barak \& Naimoğlu, 2018: 88). Bu çalışmada serilerin durağanlığının test edilmesinde Maddala ve Wu (1999) birim kök testi kullanılmıştır. Söz konusu birim kök testine göre, boş hipotez serinin durağan olmadığını yani birim kökün varlığını, alternatif hipotez ise serinin durağan olduğunu yani birim kökün olmadığını ifade etmektedir. Birim kök testleri ile serilere ait durağanlık incelemesi yapıldıktan sonra seriler arasında uzun dönemde karşılıklı bir ilişkinin bulunup bulunmadığının araştırılmasında Kao (1999) Eşbütünleşme Testi uygulanmıştır. Eşbütünleşme ilişkisi araştırıldıktan sonra ise eşbütünleşme ilişkisi olan değişkenler için Panel ARDL Yönteminin önerdiği Pesaran vd. (1999) tarafından geliştirilen (Pooled Mean Group) PMG tahmini ile kısa ve uzun dönem katsayılar tahmin edilmiştir. Panel Veri analizi ile tahmin edilmek üzere oluşturulan model, yukarıda da belirtildiği gibi Eşitlik 1 olarak sunulmuştur. Buradan hareketle Panel ARDL denklemi Eşitlik 3'teki gibi ifade edilebilmektedir:

$$
\begin{aligned}
& \Delta \mathrm{EMP}=\beta_{0}+\sum_{\mathrm{i}=1}^{\mathrm{p}} \beta_{1 \mathrm{i}} \Delta \mathrm{EMP}_{\mathrm{t}-\mathrm{p}}+\sum_{\mathrm{i}=1}^{\mathrm{p}} \beta_{2 \mathrm{i}} \Delta \mathrm{LBR}_{\mathrm{t}-\mathrm{p}}+\sum_{\mathrm{i}=1}^{\mathrm{p}} \beta_{3 \mathrm{i}} \Delta \mathrm{GRW}_{\mathrm{t}-\mathrm{p}}+ \\
& \sum_{\mathrm{i}=1}^{\mathrm{p}} \beta_{4 \mathrm{i}} \Delta \mathrm{GF}_{\mathrm{t}-\mathrm{p}}+\sum_{\mathrm{i}=1}^{\mathrm{p}} \beta_{5 \mathrm{i}} \Delta \mathrm{LRE}_{\mathrm{t}-\mathrm{p}}+\sum_{\mathrm{i}=1}^{\mathrm{p}} \beta_{6 \mathrm{i}} \Delta \mathrm{INF}_{\mathrm{t}-\mathrm{p}}+\varepsilon_{\mathrm{t}}
\end{aligned}
$$

Burada yer alan p; optimum gecikme uzunluğunu, $\Delta$; fark operatörünü, $\varepsilon t$; hata terimini, harf kısaltmaları ile verilenler ise değişkenlerin tanımındaki anlamlarını ifade etmektedir. Pesaran vd (1999)'nin metodolojisine göre Eşitlik 3 tekrar düzenlendiğinde değişkenler arasındaki uzun dönemli ilişkiyi içeren PMG modeli aşağıdaki gibidir:

$$
\begin{gathered}
\Delta \mathrm{EMP}=\beta_{0}+\sum_{\mathrm{i}=1}^{\mathrm{p}} \beta_{1} * * \Delta \mathrm{EMP}_{\mathrm{t}-\mathrm{p}}+\sum_{\mathrm{i}=1}^{\mathrm{p}} \beta_{2} * * \Delta \mathrm{LLBR}_{\mathrm{t}-\mathrm{p}}+\sum_{\mathrm{i}=1}^{\mathrm{p}} \beta_{3} * \\
* \Delta \mathrm{GRW}_{\mathrm{t}-\mathrm{p}}+\sum_{\mathrm{i}=1}^{\mathrm{p}} \beta_{4}{ }^{* *} \Delta \mathrm{GF}_{\mathrm{t}-\mathrm{p}}+\sum_{\mathrm{i}=1}^{\mathrm{p}} \beta_{5} * * \Delta \mathrm{LRE}_{\mathrm{t}-\mathrm{p}} \\
\sum_{\mathrm{i}=1}^{\mathrm{p}} \beta_{6} * * \Delta \mathrm{INF}_{\mathrm{t}-\mathrm{p}}++\beta_{7} * \Delta \mathrm{EMP}_{\mathrm{t}-1}+\beta_{8} * \Delta \mathrm{LLBR}_{\mathrm{t}-1}+\beta_{9} * \Delta \mathrm{GRW}_{\mathrm{t}-1} \\
+\beta_{10} * \Delta \mathrm{GF}_{\mathrm{t}-1}+\beta_{11} * \Delta \mathrm{LRE}_{\mathrm{t}-1}+\beta_{12} * \Delta \mathrm{INF}_{\mathrm{t}-1} \varepsilon_{\mathrm{t}}
\end{gathered}
$$

Eşitlik 3'te yer alan $\beta_{1,2,3,4,5,6}$ * terimleri uzun dönem katsayıları ifade ederken, $\beta_{1,2,3,4,5,6} * *$ terimleri ise k1sa dönemli katsayıları ifade etmektedir. Panel ARDL, değişkenlerin uzun dönem homojenliğinin yanında kısa dönem heterojenliğini de sağlamaktadır. 


\section{Modelin Bulguları}

E-7 ülkelerinde yenilenebilir enerji yatırımlarının istihdam üzerindeki etkisine yönelik analize başlamadan önce birtakım testlerin yapılması gerekmektedir. İlk olarak panel veriyi oluşturan ülkeler için yatay kesit birimleri olan ülkelerden birinde meydana gelecek bir şokun diğer ülkelere yansıması durumu olarak ifade edilen yatay kesit bağımlılı̆̆ının incelenmesi gerekmektedir. İkinci olarak ise değişkenlere ait durağanlık analizinin yapılması gerekmektedir. Bu incelemelerin yapılmasıyla ancak, çalışmada uygun yöntemin kullanılması, daha etkin ve tutarlı tahminlerin yapılabilmesi mümkün olmaktadır (Doğan, 2020: 163). Bu kapsamda ilk olarak yatay kesit bağımlılığını araştırmak amacıyla, Pesaran (2004) CD testi yapılmış ve sonuçlar Tablo 5'te verilmiştir.

Tablo: 5

\section{Yatay Kesit Bağımlılığı Test Sonuçları}

\begin{tabular}{|c|c|c|}
\hline Test istatistiği & İstatistik Değeri & Olasllk Değeri \\
\hline CD Testi & 0.614 & 0.5394 \\
\hline$* 0,10, * * 0,05 v v^{* * * 0,01}$ anlamlllık düzeylerini göstermektedir.
\end{tabular}

Tablo 5 'te ifade edilen yatay kesit bağımlılığı test sonuçlarına göre, panel veri setinde yer alan E-7 ülkelerinde yatay kesit bağımlılığının olmadığını ifade eden boş hipotez kabul edilerek, alternatif hipotez reddedilmiştir. Buna göre, örneklem grubundaki ülkelerde ele alınan modelde yatay kesit bağımlılığının olmadığı, yani E-7 ülkelerinden birinde ortaya çıkacak etkinin, diğer ülkelere yansımayacağı anlamına gelmektedir. Yani, elde edilen bu sonuca göre E-7 ülkelerinin birinde yaşanan makroekonomik bir şoktan, diğer ülkeler etkilenmeyecektir. Bu aşamadan sonra yatay kesit bağımlılı̆̆ı olmadığından dolayı, değişkenlerin durağanlık analizinde birinci kuşak birim kök testlerinin kullanılması daha doğru olmaktadır. Çalışmada birinci kuşak birim kök testlerinden Maddala ve Wu (1999) birim kök testi kullanılmış ve elde edilen test istatistikleri Tablo 6'da gösterilmektedir.

Tablo: 6

Maddala ve Wu (1999) Birim Kök Test Sonuçları

\begin{tabular}{|c|c|c|c|}
\hline Değişkenler & Test İstatistikleri & Uygun Gecikme Uzunluğu & Olasıllk Değeri \\
\hline EMP & 45.259 & 0 & $0.00^{* * * *}$ \\
\hline LLBR & 27.106 & 3 & $0.01^{* *}$ \\
\hline GRW & 42.588 & 0 & $0.00^{* * * *}$ \\
\hline GF & 4.481 & 0 & 0.99 \\
\hline$\Delta$ GF & 55.559 & 0 & $0.00^{* * *}$ \\
\hline LRE & 44.993 & 0 & $0.00^{* * *}$ \\
\hline INF & 53.090 & 0 & $0.00^{* * *}$ \\
\hline
\end{tabular}

$* 0,10, * * 0,05$ ve $* * * 0,01$ anlamlılık düzeylerini göstermektedir.

Tablo 6'da yer alan Maddala ve Wu (1999) birim kök test sonuçlarına göre EMP, LBR, GRW, RE ve INF değişkenlerinin orijinal hallerinde birim kök içermediği, yani I(0) düzeyinde durağan oldukları, GF değişkeninin ise birinci farkı alındığında durağan hale geldiği, yani I(1) düzeyinde durağan olduğu görülmektedir. 
Birim kök testleri yapıldıktan sonra, değişkenler arasında uzun dönemde eşbütünleşme ilişkisinin varlığının test edilmesinde Kao Panel Eşbütünleşme Testi uygulanmıştır. Tablo 7'de ifade edilen Kao Eşbütünleşme testi sonucuna göre, değişkenler arasında uzun dönemli bir ilişkinin varlığı tespit edilmiştir.

Tablo: 7

Kao Panel Eşbütünleşme Sonuçları

\begin{tabular}{|c|c|c|}
\hline & $\mathrm{t}$-istatistiği & Olasılık Değeri \\
\hline ADF & -2.084691 & $0.0185^{* * *}$ \\
\hline
\end{tabular}

Tablo: 8

ARDL (3,1,1,1,1) PMG Tahmin Sonuçları (2000-2019)-Uzun Dönem

\begin{tabular}{|l|c|c|c|}
\hline Değişkenler & Katsay1 & t-istatistik & Olasılık Değeri \\
\hline LLBR & -0.170455 & -3.001201 & $0.0038^{* * *}$ \\
\hline GRW & 0.182099 & 4.740662 & $0.0000^{* * *}$ \\
\hline GF & 0.442976 & 9.676932 & $0.0000^{* * *}$ \\
\hline LRE & 0.025113 & 3.471021 & $0.0009^{* * *}$ \\
\hline INF & -0.175573 & -4.285376 & $0.0001^{* * *}$ \\
\hline
\end{tabular}

$* 0,10, * * 0,05$ ve $* * * 0,01$ anlamlllık düzeylerini göstermektedir.

Tablo 8'de ifade edilen PGM Modeline ait uzun dönem katsayıları değerlendirildiğinde, katsayılar istatistiksel olarak anlamlı bulunmuştur. Buna göre incelenen ülkelerde yenilenebilir enerji yatırımlarının, istihdamı 0.025 oranında arttırdığı sonucuna ulaşılmıştır. Bu sonuç, Hilledrand vd. (2006) ve Apergis ve Salim (2015) ve Ağpak ve Özçiçek (2018)'in yaptıkları çalışmalar ile ayrışırken, Zhao ve Luo (2017) ve Kaya (2020)'nin çalışmaları ile uyumluluk göstermektedir. Başta Çin ve Hindistan olmak üzere E-7 ülkelerinin son yıllarda enerjide dışa bağımlılığın azaltılması ve ihtiyaç duyulan enerjinin ülke sınırlarında bulunan yenilenebilir enerji kaynaklarından karşılanması için uyguladıkları politikalar, söz konusu kaynakların yatırımlarını arttırmaktadır. Artan yatırımlar ise yeni istihdam alanlarını oluşturmaktadır. Böylelikle E-7 ülkeleri yenilenebilir enerjiye gerek Ar-Ge desteği vererek gerekse de hibe ve vergi indirimleri gibi politikalarla bu alanı destekleyerek hem rekabet gücüne sahip yeni teknolojiler yaratmakta hem de ihracat imkanlarını genişleterek istihdamın artmasına katkı sağlamaktadırlar. Ayrıca ülkelerin daha yeşil bir ekonomiye geçişte yenilenebilir enerji kaynaklarını daha yoğun kullanmak için hem yeni meslekler hem de yeşil ekonomi için yeni becerilere ihtiyaç duyan dönüştürülmüş meslekler yaratmaları gerekmektedir. Yenilenebilir enerji yatırımları gibi yeni teknolojilere yatırım yapan firmaların, doğru becerilere sahip çalışanları bulabilmeleri, söz konusu sektördeki istihdam oranlarını yakından etkilemektedir.

İstihdama etkisi incelenen kontrol değişkenlerden biri de toplam işgücüdür. Çalışmada E-7 ülkelerinde toplam işgücünde meydana gelen \%1'lik artışın, istihdam oranını- 0.17 oranında azalttığı görülmektedir. Nüfustaki gelişmelere bağlı olarak oluşan işgücü hem istihdam edilenleri hem de işsizleri kapsamaktadır (Esen, 2020: 9). Bu çerçevede 
elde edilen sonuca göre, E-7 ülkelerinde toplam işgücünün büyük bir bölümünün istihdam edilemediği sonucu ortaya çıkmaktadır. Söz konusu ülkelerde emek talebinin emek arzını karşılamakta yetersiz kaldığı söylenebilmektedir. Diğer bir ifadeyle bu negatif etkinin nedeni, işgücünün sermayeden daha hızlı artması olabilmektedir. Bu genellikle emek yoğun üretim gerçekleştiren E-7 ülkeleri gibi ülkelerde görülen bir durum olarak karşımıza çıkmaktadır. Söz konusu ülkelerde emek yoğun sektörler, üretimde daha yüksek bir paya sahiptir.

İstihdam üzerindeki etkisi incelenen bir diğer kontrol değişken ise ekonomik büyüme oranıdır. Çalışma sonuçlarına göre, ekonomik büyümedeki \%1'lik artış, istihdam oranını 0,18 oranında artırmaktadır. Ekonomik büyümenin, istihdam oranındaki artışını tek başına sağlamakta her zaman yeterli olamamasıyla beraber, istihdamı pozitif etkilediği yönünde genel bir görüş birliği mevcuttur. İstihdam ve ekonomik büyüme arasındaki ilişkinin incelenmesi için yapılan birçok çalışmada, istihdam için büyümenin bir ön koşul olarak gerekli olduğu fakat, yeterli olmadığı savunulmaktadır.

Çalışmada, istihdam üzerindeki etkisi incelenen değişkenlerden birini de sabit sermaye yatırımları oluşturmaktadır. Çalışma bulgularına göre, sabit sermaye yatırımlarındaki \%1'lik artış istihdam oranını 0,44 oranında yükseltmektedir. Sabit sermaye yatırımlarının ortaya çıkardığı pozitif dışsallıklar, ekonomik büyümede artışlar meydana getirerek, istihdam oranını da arttırmaktadır.

İstihdam üzerindeki etkisi incelenen son değişken ise enflasyon oranıdır. Çalışmada elde edilen ampirik sonuçlara göre enflasyon oranındaki \%1'lik artış, istihdamı -0.17 oranında azaltmaktadır. Literatürde enflasyon ile istihdam arasındaki ilişkiyi inceleyen çalışmalar iki gruba ayrılmaktadır. Bunlardan ilkini, enflasyon oranının ekonomik büyümeyi artırdığı ve bunun sonucunda istihdam oranlarının da arttığını ifade eden çalışmalar oluşturmaktadır. İkincisini ise, enflasyonun ekonomik büyüme kanalıyla istihdam üzerindeki etkisinin negatif olduğu çalışmalar oluşturmaktadır. Bu görüşlerden ilkine göre, enflasyon ülkede belirsizlik yaratarak yatırım kararlarını olumsuz etkileyerek istihdamı azaltırken, ikinci görüşe göre ise artan enflasyon, üretimi ve yatırım kararını pozitif yönde etkileyerek istihdamı artırmaktadır. Ampirik bulgular sonucunda E-7 ülkelerinde enflasyon artışı, istihdamı azaltmaktadır. 
Tablo: 9

ARDL (3,1,1,1,1) PMG Tahmin Sonuçları (2000-2019)-Kısa Dönem

\begin{tabular}{|c|c|c|c|}
\hline Değiškenler & Katsay1 & t-istatistik & Olasıllk Değeri \\
\hline$\Delta$ EMP(-1) & 0.146147 & 2.428192 & 0.0180 \\
\hline$\Delta$ EMP(-2) & 0.131475 & 1.184120 & 0.2407 \\
\hline$\Delta$ LLBR & 0.498946 & 4.319259 & 0.0001 \\
\hline$\Delta$ LGRW & -0.025124 & -0.887955 & 0.3778 \\
\hline$\Delta$ GF & 0.032932 & 0.520762 & 0.6043 \\
\hline$\Delta$ LRE & 0.056258 & 1.395643 & 0.1676 \\
\hline$\Delta$ INF & 0.008929 & 0.731787 & 0.4669 \\
\hline ECM & -0.183274 & -2.235760 & 0.0288 \\
\hline
\end{tabular}

Tablo 9'da ifade edilen değişkenlerin uzun dönem dengesine ne kadar bir hızda geri döndüğünü ifade eden Hata düzeltme Katsayısı (ECM), -0.18 olarak bulunmuştur. Bu sonuç teoriye uygun olarak negatif ve istatistiksel olarak da anlamlıdır. Buna göre, ECM terimine ait (-0.18) katsayısı, t-1 dönemindeki bir sapmanın yaklaşık \%18'inin t döneminde düzeleceğini ifade etmektedir.

\section{Sonuç ve Politik Önerme}

Günümüzde hala küresel ölçekte kullanılan birincil enerji arz kaynaklarını, fosil kökenli enerji kaynakları oluşturmaktadır. Fosil kökenli enerji kaynaklarının ise kullanımları sırasında meydana getirdiği çevresel bozulmalardan kaynaklı küresel ısınma ve bunun yanı sıra söz konusu kaynakların homojen dağılmamalarından dolayı enerjide yarattığı dışa bağımlılık sorunu, dünya ülkeleri açısından çözüm bekleyen sorunların başında gelmektedir. Gelecek 20 yıl içerisinde bir enerji dönüşümü beklenmekte ve bu dönüşümün, yenilenebilir enerji kaynaklarının lehine olması öngörülmektedir. Fosil kökenli enerji kaynaklarının yarattığı negatif dışsallıklar nedeniyle yenilenebilir enerjiye yönelik yatırımlar da son yıllarda artış göstermektedir. Yenilebilir enerji istihdam ilişkisi ise, araştırılması gereken bir makro etkileşim sorunudur.

Bu kapsamda 2000-2019 dönemi verileri kullanılarak, yenilenebilir enerji yatırımlarının istihdam üzerindeki etkileri E-7 ülkeleri için Panel ARDL yöntemi PMG Tahmincisi aracılığıyla analiz edilmiştir. Yenilenebilir enerji yatırımları ve istihdam değişkenlerine ek olarak, istihdam üzerinde etkisi olduğu düşünülen ekonomik büyüme, toplam işgücü, sabit sermaye yatırımları ve enflasyon oranları da modelde kullanılan değişkenler arasında yer almaktadır.

Çalışmada yenilenebilir enerji yatırımlarına ilişkin katsayı pozitif ve istatistiki olarak anlamlı bulunmuştur. Yenilenebilir enerji yatırımlarında meydana gelen \%1'lik artış, E-7 ülkelerinde istihdamı 0.025 oranında arttırmaktadır. Bu sonucun ortaya çıkmasında ülkelerin enerji dönüşümünü gerçekleştirmelerinde yenilenebilir enerji kaynaklarını daha yoğun kullanmak durumunda kalmaları hem yeni meslekler hem de yeşil ekonomi için yeni becerilere ihtiyaç duyan dönüştürülmüş meslekleri ortaya çıkmasının önemli bir etkisi vardır. Yenilenebilir enerji yatırımları gibi yeni teknolojilere yatırım yapan firmaların doğru 
becerilere sahip çalışanları bulabilmeleri bu sektördeki istihdam oranlarını yakından etkilemektedir. Böylelikle E-7 ülkelerinin enerjide dışa bağımlılık oranlarının azaltılması ve ihtiyaç duyulan enerjinin ülke sınırlarında bulunan yenilenebilir enerji kaynaklarından karşılanması için uyguladıkları birtakım politikalar, yenilenebilir enerji kaynaklarının yatırımlarını arttırmaktadır. Artan yatırımlar ise yeni istihdam alanlarını oluşturmaktadır. Bu çerçevede E-7 ülkelerinin yenilenebilir enerjiyle ilgili Ar-Ge çalışmalarını arttırmaları, hibe ve vergi indirimi gibi politikalarla bu alanı desteklemeleri, rekabet gücüne sahip yeni teknolojiler yaratarak, ihracat imkanlarını da genişletmektedir. Bunun da istihdam artışına katkı sağladığı düşünülmektedir. Elde edilen bu sonucun oluşmasında her bir E-7 ülkesi özelinde değerlendirildiğinde ise Çin'in, sadece E-7 grubunda değil küresel toplamda da yenilenebilir enerji sektörüne en çok yatırım yapan ve bu alanda istihdam sağlayan ülkelerin başında gelmektedir. Diğer taraftan Hindistan'da ülkenin her yıl özellikle güneş ve rüzgâr enerjisi sektörleri başta olmak üzere yenilenebilir enerji sektörüne yoğun yatırım yapması, söz konusu alanın ülke içinde istihdam oranlarına olumlu katkı yapmaktadır. Bununla birlikte Brezilya ise diğer yenilenebilir enerji teknolojilerinden daha fazla biyoyakıtlara yönelmiş ve bunun neticesinde ülke, dünyanın en büyük sıvı biyoyakıt istihdamını gerçekleştirmesi yenilenebilir enerji yatırımlarının istihdam üzerindeki olumlu etkileri bakımından önemlidir. Meksika ise, Brezilya'ya benzer şekilde biyoyakıtların ağırlıkta olduğu bir yatırım stratejisi belirlemesi ülke istihdamına olumlu olarak yansıdığı söylenebilir. Rusya, Endonezya ve Türkiye'de ise yenilenebilir enerji yatırımlarının başta hidroelektrik olmak üzere güneş ve rüzgâr enerjisi sektörlerinde yoğunlaşması sonucu bu sektörlerde yaratılan istihdam ülke içinde genel istihdama katkı sağlamaktadır. Diğer taraftan, çalışmada toplam işgücü ve enflasyonun istihdam üzerindeki etkisi negatif olurken, ekonomik büyüme ve sabit sermaye yatırımlarının ise istihdam üzerindeki etkisi pozitif olarak bulunmuştur.

Günümüzde dünyadaki birçok ülkede, özellikle kamu teşvikleri ve özel sektörün işbirliği sonucunda, yenilenebilir enerji kaynaklarına yönelik yatırımlar, gerek küresel ısınmanın önlenmesi, gerekse enerjide dışa bağımlılığı azaltmaya yönelik politikalara bağlı olarak sürekli bir artış trendi göstermektedir. Bu durum sadece yatırım anlamında değil, yarattıkları yeni teknolojiler bağlamında da istihdam kaynağı olarak görülmeye başlanmıştır. Ancak özellikle Türkiye gibi gelişmekte olan ülkelerin birçoğunda, yenilenebilir enerji kullanımı ve dolayısıyla bu alandaki yatırımlar istenilen düzeyde değildir. Bu durum ise söz konusu enerjinin yarattığı firsatları olumsuz etkilemektedir. Bu nedenle E-7 ülkeleri özelinde, tüm gelişmekte olan ülkelerin; önümüzdeki dönemde yenilenebilir enerji kaynakları kullanımı ve yatırımlarını daha da artırmalarına yönelik politikaları benimsemeleri, başta istihdam olmak üzere birçok makroekonomik değişken üzerinde olumlu katkı sağlayacağı düşünülmektedir. 


\section{Kaynaklar}

Ağpak, F. \& Ö. Özçiçek (2018), "Bir İstihdam Politikası Aracı Olarak Yenilenebilir Enerji”, Ömer Halisdemir Üniversitesi İktisadi ve İdari Bilimler Fakültesi Dergisi, 11(2), 112-128.

Aksu, L. (2017), “Türkiye'de istihdam, verimlilik ve iktisadi büyüme ilişkilerinin analizi”, İktisat Politikası Araştırmaları Dergisi, 4(1), 39-94.

Apergis, N. \& J.E. Payne (2010), "Renewable energy consumption and growth in Eurasia", Energy Economics, 32, 1392-1397.

Apergis, N. \& R. Salim (2015), "Renewable energy consumption and unemployment: evidence from a sample of 80 countries and nonlinear estimates", Applied Economics, 47(52), 56145633.

Aşkın, E. \& U. Aşkın (2019), "Yeşil İşler: Yenilenebilir enerji sektörünün istihdam yaratma potansiyeli", International Congress of Energy Economy And Security.

Barak, D. \& M. Naimoğlu (2018), "Reel döviz kurunun dış ticaret üzerindeki etkisi: Kırılgan Beşli örneği”, Ömer Halisdemir Üniversitesi İktisadi ve İdari Bilimler Fakültesi Dergisi, 11(2), 82-95.

Brady, D. \& M. Wallace (2000), "Spatialization, Foreign Direct Investment and Labor Outcomes in the American States, 1978-1996", Social Forces, The University of North Carolina Press, 79(1), 67-99.

Cameron, L. \& B. van der Zwaan (2015), "Employment factors for wind and solar energy technologies: A literature review", Renewable and Sustainable Energy Reviews, 45, 160172.

Çemrek, F. \& E. Burhan (2014), "Petrol Tüketiminin Ekonomik Büyüme Üzerindeki Etkisinin Panel Veri Analizi ile İncelenmesi: Avrupa Birliği Ülkeleri ve Türkiye Örneği”, Journal of Alanya Faculty of Business/Alanya Isletme Fakültesi Dergisi, 6(3), 47-58.

Dinçer, H. \& H. Karakuş (2020), "Yenilenebilir Enerji Yatırımları ile İstihdam Arasındaki İlişkinin Belirlenmesi: G7 Ülkeleri Üzerine Ekonometrik Bir Analiz", İstatistik ve Uygulamalı Bilimler Dergisi, 1(1), 40-49.

Elfani, M. (2011), "The impact of renewable energy on employment in Indonesia”, International Journal of Technology, 2(1), 47-55.

Ernst, C. (2005), "The FDI employment link in a globalising world: The case of Argentina, Brasil and Mexico", Employment Strategy Papers, 2005/17, Employment Analysis Unit, Employment Strategy Department.

European Comission (2014), An investment plan for Europe, COM/903 final, <http://ec.europa.eu/transparency/regdoc/rep/1/2014/EN/1-2014-903-EN-F1-1.pdf>, 12.06.2017.

Gujarati, D.N. (1999), Temel Ekonometri, (Çev. Ü. Şenesen, G.G.Şenesen), İstanbul.

Hillebrand, B. et al. (2006), "The expansion of renewable energies and employment effects in Germany”, Energy Policy, 34(18), 3484-3494. 
Hisarcıklılar, M. et al. (2009), "Can FDI Be A Panacea For Unemployment? The Turkish Case", Workshop on Labour Markets, Tade and FDI, Istanbul Technical University, October, İstanbul.

Hsiao, C. (2003), Analysis of Panel Data, Cambridge, Newyork, 366p.: 18.

IRENA (2020), Renewable Energy and Jobs-Annual Review 2020,

$<$ https://public.tableau.com/profile/irena.resource\#!/vizhome/IRENARETimeSeries/Char ts>, 01.03.2021.

Kao, C. (1999), "Spurious regression and residual-based tests for cointegration in panel data", Journal of econometrics, 90(1), 1-44.

Karaca, C. \& M. Eşgünoğlu (2017), "Yenilenebilir Enerji Yatırımlarının İstihdam Artırıcı Etkisi: Türkiye Örneği”, IMCOFE2017, Barselona.

Kaya, H. (2020), "Yenilenebilir Enerji İstihdamında Küresel Durumun Değerlendirilmesi”, Sosyal Bilimler Araştırmaları Dergisi, (2020 Sonbahar Özel Sayı I/II), 10-21.

Kralova, I. \& J. Sjöblom (2010), "Biofuels-renewable energy sources: a review”, Journal of Dispersion Science and Technology, 31(3), 409-425.

Kumar, M. (2020), “Social, Economic, and Environmental Impacts of Renewable Energy Resources", in: Wind Solar Hybrid Renewable Energy System, IntechOpen.

Lehr, U. et al. (2008), "Renewable energy and employment in Germany", Energy Policy, 36(1), 108117.

Lund, P.D. (2009), "Effects of energy policies on industry expansion in renewable energy", Renewable Energy, 34(1), 53-64.

Markandya, A. et al. (2016), "Towards a green energy economy? Tracking the employment effects of low-carbon technologies in the European Union", Applied Energy, 179, 1342-1350.

Öymen, G. \& M. Ömeroğlu (2020), "Yenilenebilir enerjinin sürdürülebilirlik üzerindeki rolü", İstanbul Ticaret Üniversitesi Sosyal Bilimler Dergisi, 19(39), 1069-1087.

Özsoy, F.N. \& A. Özpolat (2020), "Yenilenebilir Enerji ve İstihdam İlişkisi: Boothstrap Granger Nedensellik Analizi”, Uluslararası Ekonomi İşletme ve Politika Dergisi, 4(2), 263-280.

Pesaran, M.H. (2007), "A simple panel unit root test in the presence of cross-section dependence", Journal of Applied Econometrics, 22(2), 265-312.

Pesaran, M.H. et al. (1999), "Pooled mean group estimation of dynamic heterogeneous panels", Journal of the American Statistical Association, 94(446), 621-634.

Zhao, X. \& D. Luo (2017), "Driving force of rising renewable energy in China: Environment, regulation and employment", Renewable and Sustainable Energy Reviews, 68, 48-56. 
Afşar, M. \& B. Özarslan-Doğan (2021), "Yenilenebilir Enerji Yatırımları ve İstihdam İlișkisi: E-7 Ülkeleri Üzerine Bir Analiz”, Sosyoekonomi, 29(50), 547-564. 